\title{
Effect of Exclosure on Soil Properties in Comparison with Grazing Land in Guder sub- Watershed, Southern Ethiopia
}

\author{
Tamrat Sinore $^{1 *} \cdot$ Solomon Umer ${ }^{2}$ \\ ${ }^{1}$ Department of Natural Resource Management, Wachemo University, Hossana, Ethiopia \\ ${ }^{2}$ Department of Natural Resource Management, Werabe University, Werabe, Ethiopia
}

*Corresponding author: tame.eiar@gmail.com

Received: 23.08.2021; Revised: 07.11.2021; Accepted: 16.11.2021

(C) Society for Himalayan Action Research and Development

\begin{abstract}
In Ethiopia, particularly the Guder sub-watershed in the Lemo District, land degradation is a severe challenge for agricultural output. Farmers in the Guder sub-watershed in southern Ethiopia employed exclosure to combat soil degradation issues. The aim of this study was to see how exclosure affected certain soil qualities.Exclosure and neighboring grazing land with similar background histories were randomly sampled for composite soil samples. The results revealed that except for silt, sand, BD, and EC, the exclosure exhibited significantly $(\mathrm{p}<0.05)$ greater SOC, CEC, TN, $\mathrm{pH}$, and clay compared to nearby grazing area. Finally, an exclosure is a realistic technique for restoring degraded landscapes and should be implemented as soon as possible.
\end{abstract}

Key Words: Exclosure, Grazing land, Guder sub-Watershed,Soil Properties

\section{Introduction}

Land productivity, biodiversity, soil fertility and other ecosystem services all suffer from degradation of the land. For example, the deforestation, agricultural land expansion and overgrazing of Ethiopia caused a serious deterioration of the dry land vegetation (Lemenih et al., 2005; Mengistu et al., 2005). This is related to increasing population and depletion of natural resources (Mekuria et al., 2009, Hurni et al., 2005). As a result, there is an urgent need to adequately restore, manage, use, and maintain them, which requires a deep understanding of stand structures as well as the diversity and quality of woody species. To prevent further soil degradation, Ethiopia has undertaken a number of programs, including soil and water conservation and the establishment of exclosure (Nedessa, 2003). About three decades ago, communities in Ethiopia's highlands began restoring biodiversity and managing their environmental services entirely, and forestry was identified as one of the primary pillars of climate-resilience strategy in green economy (Mekuria and Yami, 2013; Mekuria and Aynekulu, 2011). At the same time, Ethiopia's government has committed to restoring 15 million hectares of deteriorated soils, or nearly a sixth of the country's land, by 2025, probably using 1,42 Gt of $\mathrm{CO}$ 2. When compared to communal grazingland, exclosure has a significant impact on species richness (Emiru et al., 2006; Tefera, 2001), soil nutrient supply (Mekuria et al., 2007; Tekalign et al., 2005; Mekuria, 2013), soil organic carbon (Tizita, 
2016; Gebregergs, 2019), and moisture availability (Qasim et al., 2019).Soil organic matter is a significant soil component to change soil conditions, improve soil water holding capability, limit soil erosion, give plant accessible nutrients and enhance soil cation exchange capabilities (Pietrzykowsk et al., 2017). Exclosure also promotes soil structure and moisture and soil variation and movement (Bot, 2005).

Exclosure effects on soil property were found to be site specific in various investigations. Differences in temperature, vegetation type, and soil qualities could all play a role in regenerating degraded lands (Allen et al., 2013; Anderson et al., 2007). The community in the Guder subwatershed of the Lemo district implemented a 10-year old exclosure to address land degradation issues and provide a sustainable environment. In the Guder sub-watershed, however, the impacts of exclosure on the advancement of soil qualities are not taken into account. In this context, generating scientific data for long-term soil resource management is critical. In order to examine the impacts of exclosure on selected soil chemical $(\mathrm{pH}, \mathrm{EC}$, SOC, TN, and Av.P) and physical (texture and bulk density) parameters to neighboring grazing land, this study was done.

\section{Materials and Methods}

\section{Study area description}

The research was carried out in the Guder subwatershed in the Lemo district of Hadiya Zone in southern Ethiopia. The study site is around 15 kilometers from Hossana town in northwest Ethiopia, and 232 kilometers from Addis Ababa, Ethiopia's capital. Lemo District is located between $7^{\circ} 22^{\prime} 00^{\prime \prime}$ and $7^{\circ} 45^{\prime} 00^{\prime \prime} \mathrm{N}$ latitude and $37^{\circ} 40^{\prime} 00^{\prime \prime}$ and $38^{\circ} 00^{\prime} \mathrm{E}$ longitude, with altitudes ranging from 1900 to 2700 meters above sea level. The administrative boundary of Lemo District is Silte Zone in the North, Kembata Tembaro zone in the South, Gombora District in North West, Anlemo District in the North East, and Shashogo District in the East (LWARDO, 2017). The mean annual rainfall is 900 $1400 \mathrm{~mm}$ and temperature between $13^{\circ} \mathrm{C}$ to $23^{\circ} \mathrm{C}$. Mixed agriculture (crop and livestock) is the main livelihood (LWARDO, 2017).

\section{Soil sampling and laboratory analysis}

Before beginning operations, a reconnaissance study was done to determine the presence of neighboring grazing land with a similar history of exclosure in the Guder sub-watershed. Social standards among stakeholders have been created to limit the disturbance caused by humans and livestock on grazing area. The exclosure is roughly 10 acres in size, with an elevation of 2200-22300 meters above sea level. It is free of domestic animals and humans, and it is maintained by natural regeneration, which began in 2011.

The exclosure region being part of the grazing land used before it was established, the exclosure was similar to the grassing land before 
the land was established, implying natural rehabilitation of a piece of degraded grazing ground by exclusion in the past. After that, the exclosure and the pasture fields were believed to be almost homogeneous before the exclosure. Then three transect lines were established across the pit at 100 meters to reduce variability in soil qualities due to changes in elevation on each exclosure and grazing soil.On both land management measures, three sampling quadrants $(20 \mathrm{~m} 20 \mathrm{~m})$ were randomly established along each transect line. Five points (four from the corners and one in the center of each quadrant) were taken from surface soils at a depth of 0-30 $\mathrm{cm}$ to produce one composite soil. These samples were carefully mixed, and a composite soil sample of approximately 1 pound was created. For bulk density analysis, undisturbed samples were obtained from the exclosure and grazing ground using a core sampler.

A plastic bag packaged, labeled and transmitted the composite soil samples to the laboratory. Soil samples were air-dried at room temperature and sieved through $2 \mathrm{~mm}$ for laboratory investigation of selected physicochemical parameters of soil, except for soil bulk density. After organic matter has been removed by hydrogen peroxide $(\mathrm{H} 2 \mathrm{O} 2)$, soil texture was evaluated using the hydrometric method and the soil was dispersed with sodium hexametaphosphate (Boyoucos, 1962) (NaPO3).The quantity of oven-dried soil $\left(105^{\circ} \mathrm{C}\right)$ divided by its volume was used to compute soil bulk density using the core technique (Chen et al., 2010). In a supernatant suspension of 1:2.5, soil: water suspension, the soil $\mathrm{pH}$ was measured potentiometrically with a digital pH meter (Carter, 1993). A conductivity meter was used to measure electrical conductivity (EC) in saturated soil paste extracts after suction was applied (Okalebo et al., 2002). The soil organic carbon (SOC) content was determined using the Walkley and Black (1934) method. The available phosphorous (Av.P) was evaluated using Olsen's extraction (1965) method, and the cation exchange capacity (CEC) was determined using $1 \mathrm{M}$ NH4OAc at pH 7 extraction (Jackson, 1958).

\section{Statistical Analysis}

A student's t-test for independent variables $(\mathrm{p}<$ $0.05)$ confirmed differences in mean values of physico-chemical parameters from the exclosure and its surrounding grazing field. Pearson correlations between soil physico-chemical parameters in the exclosure and neighboring grazing field were also investigated $(\mathrm{p}<0.01$ and $0.05)$.

\section{Result and Discussion}

\section{Effects of exclosure on soil physico-chemical properties} Soil pH:The results showed that with the exclosure, soil reaction $(\mathrm{pH})$ was significantly $(\mathrm{p}<0.05)$ improved, followed by grazing land (Table 1). The exclosure had the greatest mean $\mathrm{pH}$ value (5.63 \pm 0.26$)$, while the gazing land had the lowest $(5.34 \pm 0.08)$ (Table 1). The lower 
mean $\mathrm{pH}$ value on grazing land could be due to the lower soil organic matter content and lower base saturation percentage. This conclusion contrasts with Tamrat and Dinsa (2021); Fantaw et al. (2015); and Mekuria et al. (2007), who found no significant variation in soil $\mathrm{pH}$ between exclosure and degraded pastures.

Electrical conductivity (EC):The exclosure had the highest mean $(0.128 \pm 0.03)$ value of $\mathrm{EC}$, whereas the grazing land had the lowest mean $(0.067 \pm 0.02)$ (Table 1$)$. The statistical results showed that there was no statistically significant ( $p>0.05)$ difference in EC between exclosure and grazing land in the studied area. The lack of salinity or/and sodicity, as well as the study site's location in a high-rainfall area, are likely reasons. The association between $\mathrm{pH}$ and EC $(\mathrm{r}=0.50 * *)$ was found to be positive and highly significant.

Soil organic carbon (SOC \%): Exclosure had a significant $(\mathrm{p}<0.05)$ impact on soil organic carbon than grazing land, as shown in Table 1. Exclosure and grazing land had mean SOC values of $2.33 \pm 0.44$ and $1.85 \pm 0.37$, respectively. Exclosure soil has significantly $(\mathrm{p}<0.05)$ higher soil organic carbon than grazing land, owing to improved management, establishment, and subsequent increased organic matter input derived from woody species biomass, as well as reduced soil erosion through effective ground cover.This finding is supported by Mekuria and Veldkamp (2005); Tamrat and Dinsa, (2021) in that grazing land and exclosure differ considerably in their soil organic carbon content reflecting the higher amount in exclosures than in open grazing land.Enclosures, according to Descheemaeker et al. (2005), improve the hydrology and soil inside forested land in several ways, including preventing physical soil loss, maintaining or increasing soil water holding capacity, protecting or increasing top soil depth, preventing soil nutrient loss, and increasing soil organic matter.

Soil total nitrogen (TN \%):The statistical results revealed that the difference in $\mathrm{TN}$ between exclosure and grazing land was substantially significant $(\mathrm{p}<0.05)$ (Table 1$)$. Exclosure had the highest mean $(0.20 \pm 0.03)$ value, while grazing land had the lowest average $(0.190 \pm 03)$ value. This could be due to differences in soil organic content and soil erosion intensities, implying that the biophysical conservation measure of exclosure has indirectly contributed to land management sustainability by replenishing soil nutrients.The exclosure's higher total nitrogen content is due to higher soil organic matter content and the presence of leguminous plants with the ability to fix nitrogen from the atmosphere through their roots' nodules. Abiy (2008) and Katrien (2007) found that when exclosure was compared to grazing pasture and degraded land in different parts of Ethiopia, there was a substantial difference in total nitrogen.

Available Phosphorous (Av.P):The findings revealed a substantial $(\mathrm{p}<0.05)$ difference in 
soils between the exclosure and neighboring grazing field (Table 1). The highest mean $(6.12 \pm 0.78)$ and lowest mean $(4.84 \pm 0.81)$ values of the Av.P were found in exclosure and grazing land, respectively (Table 1). The greater clay content and organic carbon accumulation in exclosure could be the cause. Organic carbon was favorably and significantly associated with total nitrogen $(\mathrm{r}=0.91 * *)$ and positively associated with Av.P and clay content $(r=0.17$ $\& r=0.30)$, according to the correlation (Table 2).

\section{Cation Exchange Capacity (CEC):Exclosure} and grazing land had a substantial $(\mathrm{p}<0.05)$ impact on CEC, as shown in Table 1. The highest mean value $(28.82 \pm 2.99)$ was found in exclosure, whereas the lowest mean value
(26.92 \pm 2.17$)$ was found on grazing land. The exclosure may have collected significant levels of organic carbon, clay, and has a larger capacity to store cations, resulting in increased potential fertility in the soil. Furthermore, soil CEC is projected to rise when the organic carbon content of the soil improves. Furthermore, soil CEC was shown to be favorably linked with clay $(\mathrm{r}=0.34)$ and organic carbon $(\mathrm{r}=0.72 * *)$ (Table 2). This discovery is backed up by Tamrat and Dinsa (2021) and Kibret (2008), who found that soil CEC is linked to clay and organic colloids, and that organic matter, in particular, improves soil CEC. Similarly, Abiy (2008) found that the mean CEC in exclosure was higher than in the adjacent deteriorated site.

Table 1: The effects (mean \pm MSD) of exclosure on soil physicochemical properties in the Guder sub-watershed

\begin{tabular}{|c|c|c|c|}
\hline Soil Parameters & Land & easures & $\mathrm{P}$-value \\
\hline $\mathrm{pH}$ & $\begin{array}{l}\text { Exclosure } \\
5.63 \pm 0.26\end{array}$ & $\begin{array}{c}\text { Grazing land } \\
5.34 \pm 0.08\end{array}$ & $0.0001 *$ \\
\hline $\mathrm{EC}(\mathrm{ds} / \mathrm{m})$ & $0.128 \pm 0.03$ & $0.067 \pm 0.02$ & $0.0623 \mathrm{~ns}$ \\
\hline $\begin{array}{c}\text { SOC }(\%) \\
\text { TN }(\%) \\
\text { Av.P (ppm) }\end{array}$ & $\begin{array}{l}2.33 \pm 0.44 \\
0.20 \pm 0.03 \\
6.12 \pm 0.78\end{array}$ & $\begin{array}{l}1.85 \pm 0.37 \\
0.19 \pm 0.03 \\
4.84 \pm 0.81\end{array}$ & $\begin{array}{l}0.0010^{*} \\
0.0001 * \\
0.0001 *\end{array}$ \\
\hline $\mathrm{CEC}(\operatorname{cmol}(+) / \mathrm{kg}$ & $28.82 \pm 2.99$ & $26.92 \pm 2.17$ & $0.0218 *$ \\
\hline $\begin{array}{c}\text { Sand }(\%) \\
\text { Silt }(\%) \\
\text { Clay }(\%) \\
\text { BD }\left(\mathrm{g} / \mathrm{cm}^{3}\right)\end{array}$ & $\begin{array}{c}19.75 \pm 3.19 \\
33.25 \pm 2.76 \\
43 \pm 3.85 \\
1.08 \pm 0.05\end{array}$ & $\begin{array}{c}21.00 \pm 2.82 \\
34.25 \pm 2.81 \\
41 \pm 4.11 \\
1.16 \pm 0.03\end{array}$ & $\begin{array}{c}0.0001^{*} \\
0.4421 \mathrm{~ns} \\
0.0005^{*} \\
0.0006^{*}\end{array}$ \\
\hline
\end{tabular}


Table 2: Correlations among the soil physico-chemical properties of the exclosure and grazing land

\begin{tabular}{|c|c|c|c|c|c|c|c|c|c|c|}
\hline & $\mathrm{OC}$ & $\mathrm{TN}$ & $\overline{\mathrm{CEC}}$ & $\mathrm{EC}$ & $\mathrm{pH}$ & Av.P & Sand & Clay & Silt & $\overline{\mathrm{BD}}$ \\
\hline$\overline{\mathrm{OC}}$ & 1 & & & & & & & & & \\
\hline $\mathrm{TN}$ & $0.91 * *$ & 1 & & & & & & & & \\
\hline CEC & $0.72 * *$ & $0.56^{*}$ & 1 & & & & & & & \\
\hline $\mathrm{EC}$ & $0.56^{*}$ & 0.43 & $0.82 * *$ & 1 & & & & & & \\
\hline $\mathrm{pH}$ & $0.55^{*}$ & 0.38 & $0.50^{*}$ & $50 * *$ & 1 & & & & & \\
\hline Av.P & 0.17 & -0.05 & 0.13 & 0.34 & 0.36 & 1 & & & & \\
\hline Sand & -0.23 & -0.21 & $-0.31 *$ & -0.05 & -0.46 & -0.15 & 1 & & & \\
\hline Clay & 0.30 & 0.27 & 0.34 & 0.04 & -0.03 & $-0.51^{*}$ & $-0.73^{* *}$ & 1 & & \\
\hline Silt & -0.18 & -0.16 & 0.31 & -0.01 & 0.22 & 0.29 & -0.00 & $-0.67 * *$ & 1 & \\
\hline BD & $-0.99 * *$ & $0.77 * *$ & -0.76 & $-0.64 * *$ & $-0.57 *$ & -0.19 & 0.33 & -0.30 & 0.87 & 1 \\
\hline
\end{tabular}

Soil particle size fractions (sand, silt and

clay): Exclosure had a substantial $(p<0.05)$ effect on the clay and sand fractions of the soils, but there was no significant $(\mathrm{p}>0.05)$ variation in silt concentration (Table 1). The clay had the highest mean value $(43 \pm 3.85)$ in the exclosure and the lowest mean $(41 \pm 4.11)$ in the neighboring grazing land. In contrast, the greatest mean $(21.00 \pm 2.82 \& 34.25 \pm 2.81)$ sand and silt values were found in grazing land, whereas the lowest mean $(19.75 \pm 3.19 \& 33.25 \pm 2.76)$ values were found in the exclosure.The higher clay content in the exclosure could be due to relatively low soil erosion in the site, whereas the lower clay in the grazing land could be due to relatively higher sheet erosion, which could reflect low organic matter, livestock trampling, and sparse vegetation aggravate soil erosion, removing clay from the adjacent degraded land selectively. This conclusion supports Tamrat and Dinsa (2021) and Gachene and Kimaru (2003) findings that clay particles are lighter than sand particles and can be easily moved once detached by erosion.

Soil bulk density (BD): Exclosure (Table 1) had a significant $(\mathrm{p}<0.05)$ effect on soil bulk density, with grazing land having the highest mean $(1.16 \pm 0.03)$ value and exclosure having the lowest mean (1.08 \pm 0.05$)$ (Table 1). Grazing land has the highest mean value of bulk density due to the higher compaction effect of grazing and erosion of the top soil due to a lack of vegetation cover. A negative link was 
Rift Valley of Ethiopia (M.Sc. Thesis)

Addis Ababa University.

Allen D.E, Pringle M.J, Bray S, Hall T.J, Reagain, P.O.O, Phelps D, Cobon D.H,Bloesch P.M,Dalal, E.C (2013) what determines soil organic carbon stocks in the grazing lands of northeastern Australia? Soil Res. 51, 695-706

Anderson TM, Ritchie ME, McNaughton SJ (2007) Rainfall and soils modify plant community response to grazing in Serengeti national park. Ecology, 88, $1191-1201$

Bot A, Bentites J (2005) The Importance of Soil Organic Matter: Key to Drought Resistant Soil andSustainable Food Production. FAO Soils Bulletin-80, Rome, Italy, pp. 5-48

Bouyoucos GJ (1962) Hydrometer method improvement for making particle size analysis of soils. J Agron 54:179-186

Bewket W, Stroosnijder L (2003) Effects of agro ecological land use succession on soil properties in the Chemoga watershed, Blue Nile basin, Ethiopia. Geoderma 111:85-98

Abiy T (2008) Area closure as a strategy for land management: A case study at Kelala Dalacha enclosure in the Central
Carter MR (1993) Soil sampling and methods of analysis. Lewis Publishers, Boca Raton 
Chen DD, Zhang SH, Dong SK, Wang XT, Du GZ (2010) Effect of land-use on soil nutrients and microbial biomass of an alpine region on the northeastern Tibetan plateau, China. Land DegradDev 21:446-452

Descheemaeker K, Nyssen J, Rossi J, Poesen J, Mitiku Haile, Raes D, Muys B. Moeyersons J, Deckers J (2005) Sediment deposition and pedogenesis in exclosures in the Tigray Highlands, Ethiopia. Geoderma, 32, 291-314

Emiru B, Demel T, Barklund P (2006) Actual and potential contribution of exclosures to enhance biodiversity of woody species in dry lands of Eastern Tigray. J. Dry Lands, 1, 134-147

Fantaw Y, Getachew A, Abdu A(2015) Soil property variations in relation to exclosure and open grazing land use types in the Central Rift Valley area of Ethiopia. Environ. Syst. Res, 4, 1-10

Gebregergs T, Tessema Z.K., Solomon N, Birhane E (2019) Carbon sequestration and soil restoration potential of grazing lands under exclosure management in a semi-arid environment of northern Ethiopia. Ecol. Evol. 9, 6468-6479.

Gachene C, Kimaru G. (2003) Soil fertility and land productivity: A guide for extension workers in Eastern Africa. Regional Land Management Unit (RELMA), Swedish International Development Cooperation Agency (Sida)

Hurni H, Kebede T, Gete Z, (2005). The implications of changes in population, land use, and land management for surface runoff in the Upper Nile Basin area of Ethiopia. Mt. Res. Dev. 25: 145149

Jackson M L (1958). Soil Chemical Analysis; Prentice Hall: Englewood Cliffs, NJ, USA

Katrien D (2007). Pedological and hydrological effects of vegetation restoration in exclosures established on degraded hill slopes in the Highlands of Northern Ethiopia

Kibret M (2008). Enclosures as viable options for rehabilitation of degraded lands and biodiversity conservation: The case of Kalluworeda, Southern Wello [Master Thesis]. Addis Ababa University (Unpublished)

LWARDO (2017) Land use profile of lemo woreda agricultural and development office. Physical planning Department, Hossana, p 65 
Lemenih M, Karltun E, Olsson M (2005). Soil organic matter dynamics after deforestation along a farm field chronosequence in southern highlands of Ethiopia. Agriculture, Ecosystems and Environment 109: 9-19

Mekuria W (2013) Conversion of communal grazing lands into exclosures restored soil properties in the semi-arid lowlands of Northern Ethiopia. Arid Land Res Manag 27:153-166

Mekuria W, Aynekulu E (2011) Exclosure land management for restoration of the soils in degraded communal grazing lands in northern Ethiopia. Land DegradDev 24(6):528-538

Mekuria W, Veldkamp E (2005) Impacts of land use changes on soil nutrients and erosion in Tigray. Proceedings on International Agricultural Research for Development, Ethiopia, pp 11-13

Mekuria W, Veldkamp E, Mitiku H, Nyssen J, Muys B, Kindeya G (2007) Effectiveness of exclosures to restore degraded soils because of overgrazing in Tigray, Ethiopia. J Arid Environ 69:270-284

Mekuria W, Veldkamp, E, Mitiku H, Kindeya G, Muys, B, \&Nyssen, J (2009) Effectiveness of exclosures to Control soil erosion and local community Perception on soil erosion in Tigray, Ethiopia. African Journal of Agricultural Research, 4, 365-377

Mekuria W, Yami, M (2013) Changes in woody species composition following establishing exclosures on grazing lands in the lowlands of Northern Ethiopia. African Journal of Environmental Science and Technology Vol. 7(1), pp. $30-40$

Mengistu T, Teketay D, Håkan H, Yemshaw Y (2005) The role of exclosures in the recovery of woody vegetation in degraded dryland hillsides of central and northern Ethiopia. J Arid Environ 60:259-281

Nedessa, B (2003). Soil and Water Conservation Program in the Amhara National Regional State. In: A. Tillahun (ed). Natural Resources Degradation and Environmental Concerns in the Amhara National Regional State: Impact on Food Security. Proceedings of the Natural Resources Management Conference, July 24-26, 2002, Bahir Dar, Ethiopia

Neelo J, Teketay, D, Kashe K, Masamba, W (2015). Stand Structure, Diversity and Regeneration Status of Woody Species 
International Journal of River Basin

Management

Tefera M (2001). The Role of Enclosures in the Recovery of Woody Vegetation in Degraded Dry Land Hillsides of Central and Northern Ethiopia. Master's Thesis, Swedish University of Agricultural Sciences, with WGCF in Ethiopia Swedish

Tekalign T, Demel T, Hulten H, Yonas Y (2005) The role of exclosures in the recovery of wood vegetation in degraded dry land hillsides of central and northern Ethiopia. J. Arid. Environ, 60, 259281

Tizita E (2016). Dynamics of Soil PhysicoChemical Properties in Area Closures at Hirna Watershed of West Hararghe Zone of Oromia Region, Ethiopia. Int. J. Soil Sci 11, 1-8

Walkley A, Black CA (1934) An examination of different methods for determining soil organic matter and the proposed modification of the chromic acid titration method. J Soil Sci 37:29-38

Tamrat S, \& Dinsa D (2021) Area exclosure effects on soil properties and woody species diversity in Amelake subwatershed, Southern Ethiopia, 